Bidik

Vol. 1 No. 1 Oktober 2020

$13-19$

\title{
Peningkatan Kemampuan Menulis Artikel Pustakawan Di Pekanbaru
}

\author{
Rosman, $\mathrm{H}^{*}$, Nining Sudiar, Hadira Latiar \\ Fakultas Ilmu Budaya, Universitas Lancang Kuning \\ *Email : rosman20@,unilak.ac.id
}

\begin{abstract}
Scientific articles are scientific papers from research results communicated in scientific publications, such as journals, magazines, or other publications. Librarians as functional personnel are required to make a positive contribution to the nation's change, one of which is to produce scientific papers published in scientific publications. The community service activities aim to provide understanding, improve and provide the ability to compile research results and the ability to write scientific articles to librarians in Pekanbaru. The method used in this activity is in the form of workshops delivered with lecture techniques, question and answer, and practice. To find out the extent of participants' acceptance and understanding, as well as the ability of participants, at the beginning and end of the training an evaluation or evaluation is carried out by filling in the pretest and post-test sheets. Based on the results of the tests that have been conducted, it is known that the participants experienced an increase after training in writing scientific articles. On the understanding of the concept of scientific articles increased by 30.75\%, while the ability of strategies and scientific article writing techniques increased by $29.64 \%$. in the training participants were very enthusiastic and active in participating in training activities writing scientific articles from beginning to end.
\end{abstract}

Keywords: scientific articles, pekanbaru, librarians.

\begin{abstract}
Abstrak
Artikel ilmiah merupakan karya tulis ilmiah hasil penelitian yang dikomunikasikan dalam publikasi ilmiah, seperti jurnal, majalah, atau publikasi lainnya. Pustakawan sebagai tenaga fungsional yang dituntut untuk memberikan kontribusi positif bagi perubahan bangsa, salah satunnya adalah dengan menghasilkan karya tulis ilmiah yang diterbitkan dalam publikasi ilmiah. Kegiatan pengabdian kepada masyarakat ini bertujuan memberikan pemahaman, meningkatkan, dan memberi bekal kemampuan menyusun hasil penelitian dan kemampuan menulis artikel ilmiah kepada pustakawan di Pekanbaru. Metode yang digunakan dalam kegiatan ini yaitu dalam bentuk workshop yang disampaikan dengan teknik ceramah, tanyajawab, dan praktik. Untuk mengetahui sejauh mana penerimaan dan pemahaman peserta, serta kemampuan peserta, pada awal dan akhir pelatihan dilakukan penilaian atau evaluasi dengan mengisi lembar pretest dan post-test. Berdasarkan hasil tes yang sudah dilakukan diketahui bahwa peserta mengalami peningkatan setelah dilakukan pelatihan menulis artikel ilmiah. Pada pemahaman tentang konsep artikel ilmiah mengalami peningkatan sebesar $30,75 \%$, sedangkan pada kemampuan strategi dan teknik menulis artikel ilmiah mengalami peningkatan sebesar 29,64\%. dalam pelatihan tersebut peserta sangat antusias dan aktif dalam mengikuti kegiatan pelatihan menulis artikel ilmiah dari awal sampai akhir.
\end{abstract}

Kata kunci: artikel ilmiah, pekanbaru, pustakawan. 


\section{Pendahuluan}

Dalam Keputusan Presiden No.87 tahun 1999 disebutkan bahwa yang dimaksud dengan jabatan fungsional pegawai negeri sipil adalah kedudukan yang menunjukkan tugas, tanggung jawab, wewenang dan hak seorang pegawai negeri sipil dalam suatu satuan organisasi yang dalam pelaksanaan tugasnya didasarkan pada keahlian dan/atau keterampilan tertentu serta bersifat mandiri (Indonesia P. R., 1999). Hal tersebut mengandung arti bahwa seorang pejabat fungsional dalam menjalankan tugas dan fungsinya lebih mengutamakan aspek profesionalisme dan kemandirian.

Jabatan pustakawan sebagai salah satu jabatan fungsional di Indonesia telah berjalan sekitar 17 (tujuh belas) tahun sejak dikeluarkannya Keputusan Menpan no.18/1988 tentang jabatan fungsional dan angka kreditnya dan mengalami beberapa penyempurnaan dengan dikeluarkannya Keputusan Menpan No. 33/1998 dan terakhir dengan Keputusan Menpan N0.132/KEP/M.PAN/12/2002.

Dari Surat Keputusan tersebut di atas disebutkan butir kegiatan pustakawan yang menjadi tugas dan tanggung jawabnya yang terdiri atas enam bidang, yaitu : (1) pendidikan; (2) pengorganisasi dan pendayagunaan koleksi bahan pustaka/sumber informasi; (3) pemasyarakatan perpustakaan, dokumentasi dan informasi; (4) pengkajian dan pengembangan perpustakaan, dokumentasi dan informasi; (5) pengembangan profesi dan (6) penunjang (Indonesia M. R., 2002). Dalam pelaksanaan tugas kepustakawanan terdapat beberapa pejabat fungsional pustakawan tidak bisa mengusulkan kenaikan jabatan karena tidak terpenuhinya sejumlah angka kredit yang dipersyaratkan untuk kenaikan jabatan setingkat lebih tinggi. Salah satu faktor tidak terpenuhinya angka kredit tersebut disebabkan pejabat fungsional yang bersangkutan dalam pengumpulan angka kredit lebih banyak mengandalkan unsur-unsur kegiatan di luar unsur pengembangan profesi yang bobot kreditnya relatif kecil, sedangkan unsur pengembangan profesi yang memiliki bobot kredit yang cukup tinggi kurang mendapat perhatian.

Unsur pengembangan profesi memiliki bobot nilai yang tinggi dibandingkan unsur-unsur yang lain dan oleh sebab itu, pejabat fungsional pustakawan perlu memberikan perhatian terhadap unsur ini agar usaha memperoleh sejumlah angka kredit yang dipersyaratkan untuk kenaikan jabatan setingkat lebih tinggi dapat terpenuhi. Dalam Keputusan Menpan No.132/KEP/M.PAN/12/2002 tentang jabatan fungsional pustakawan dan angka kreditnya terutama yang menyangkut unsur pengembangan profesi, terdapat enam komponen dan salah satu unsur yang mendapat nilai tertinggi adalah komponen membuat karya ilmiah (Indonesia M. R., 2002). Seperti diketahui bahwa jabatan fungsional pustakawan merupakan jabatan profesional dalam pengertian suatu jabatan dimana pejabat fungsional pustakawan untuk dapat melaksanakan tugas dan fungsinya dituntut memiliki keahlian dan kecakapan khusus, sehingga menjadi tugas dan kewajiban pejabat fungsional pustakawan untuk mengembangkan jabatannya secara profesional. Pengembangan profesi jabatan fungsional pustakawan merupakan usaha pustakawan dalam rangka meningkatkan kualitas kinerjanya dan profesionalisasi tenaga kependidikan agar dapat memberikan manfaat dan nilai tambah dalam menjalankan tugas dan fungsinya.

Mengingat angka kredit yang diberikan kepada karya tulis ilmiah lebih tinggi 
dari pada komponen unsur lainnya, sebaiknya setiap pejabat fungsional pustakawan harus berusaha memperluas wawasan dan keterampilan dalam bidang penulisan karya ilmiah ini, disamping unsur-unsur lainnya. Hal ini disebabkan karya tulis ilmiah bersifat akademis atau menunjang nilai-nilai keilmuan dibandingkan dengan bidang-bidang kegiatan lainnya. Para pejabat fungsional pustakawan diharapkan memiliki kemampuan untuk menulis karya ilmiah dan yang perlu ditimbulkan adalah kemauan, keberanian dan kreativitas pustakawan untuk melaksanakan tugas ini. Adapun topik atau permasalahan yang dibahas bisa mencakup bidang tugas sesuai keahlian, pengalaman pustakawan dalam menjalankan tugas dan fungsinya, langkah-langkah penanggulangan kasus tugas sehari-hari dan lain-lain yang kalau dibahas dan disusun secara sistematis, analitis dan kritis dapat menghasilkan karya tulis ilmiah berupa makalah, laporan penelitian, buku, artikel dan lain sebagainya.

Permasalahan utama yang dihadapi oleh mitra adalah terbatasnya kemampuan pustakawan dalam pembuatan karya tulis ilmiah, sehingga pustakawan mengalami kesulitan. Hal ini disebabkan kurangnya pengetahuan mengenai pendalaman mengenai hal tersebut serta kemampuan dalam menerapkan atau memindahkan ilmu dalam wujud penulisan karya tulis ilmiah.

Terkait permasalahan tersebut, maka solusi yang ditawarkan adalah diadakannya pelatihan menulis karya tulis ilmiah yang sesuai dengan pedoman penulisan karya tulis ilmiah. Diharapkan, hasil kegiatan ini memberikan jasa yang diberikan kepada mitra guna meningkatkan kemampuan pustakawan dalam membuat karya tulis ilmiah yang baik dan benar, serta luaran yang diharapkan ialah publikasi ilmiah di jurnal/prosiding, dan publikasi di media masa.

\section{Pedekatan Pelaksanaan Program}

Kegiatan pelatihan ini diselenggarakan dengan diawali dengan mengajak para peserta untuk mulai memfokuskan kegiatan hanya pada pelatihan menulis artikel ilmiah. Hal ini dimaksudkan agar hasil pelatihan ini berjalan secara optimal. Selain itu, metode yang digunakan dalam kegiatan ini adalah ceramah, tanya-jawab, dan praktek. Praktek/latihan dilakukan setelah kegiatan inti berlangsung atau diakhir kegiatan inti, dengan harapan peserta dapat mengetahui secara langsung aplikasi materi yang disampaikan oleh narasumber.

Berkaitan dengan kegiatan tersebut, tim melakukan evaluasi dengan memberikan 10 (sepuluh) pertanyaan dalam bentuk pretest, post-test serta mengajukan pertanyaan langsung. Pretest diberikan diawal kegiatan sebelum berlangsungnya kegiatan, post-test diberikan setelah berakhirnya materi atau di akhir kegiatan, serta pertanyaan langsung diberikan secara lisan saat kegiatan sedang berlangsung. Untuk praktek, setelah kegiatan pemberian materi selesai, pemateri memberikan tugas untuk praktek menulis artikel dengan tema perpustakaan, pustakawan, dan kepustakawanan. Tema-tema tersebut ditentukan oleh pemateri secara acak. 


\section{Pelaksanaan Program}

Kegiatan Pengabdian Kepada Masyarakat yang dilaksanakan dalam bentuk pelatihan dalam rangka peningkatan menulis artikel bagi pustakawan di Pekenbaru ini telah selesai dilaksanakan sesuai dengan rencana. Mitra dalam kegiatan Pengabdian Kepada Masyarakat ini adalah para pustakawan yang bekerja di perpustakaan sekolah dan perguruan tinggi baik negeri dan swasta di Pekanbaru. Berdasarkan daftar hadir yang ada, tercatat 30 orang perserta hadir dalam kegiatan ini. Selain pustakawan, kegiatan ini juga dihadiri oleh para mahasiswa Prodi Ilmu Perpustakaan Universitas Lancang Kuning. Kegiatan ini dilaksanakan di Fakultas Ilmu Budaya Ruang Seminar yang berlokasi di Jalan Yos Sudarso Km. 8 Rumbai Pekanbaru.

Sebelum kegiatan dilaksanakan, tim melakukan analisis situasi dan kebutuhan di lapangan. Kegiatan ini dilakukan dengan berdiskusi dengan Mitra dan survey singkat di lapangan terkait kompetensi pustakawan dalam menulis artikel ilmiah. Setelah tim melakukan analisis situasi dan permasalahan mitra, masing-masing mitra menyambut baik sangat baik yang akan dilaksanakan, yakni pelatihan menulis artikel bagi pustakawan. Bentuk partisipasi mitra ditunjukkan dengan kesediaannya untuk menyiapkan tempat, mendistribusikan undangan, dan menjadi penanggung jawab kegiatan sehingga kegiatan berlangsung dengan baik. Antusiasme dan semangat peserta pelatihan sangat tinggi. Beragam pertanyaan dan tanggapan pun ditunjukkan kepada pamateri. Tampak pada wajah peserta keinginan untuk dapat menulis artikel ilmiah. Mereka sadar bahwa pustakawan memiliki posisi strategis dalam memberikan masukan, sumbangan pemikiran, dan memajukan institusi yang menaunginya melalui perpustakaan dan kemampuan personal yang baik. Hal ini karena perpustakaan merupakan jantungnya sebuah institusi pendidikan yang menunjang proses kegiatan belajar mengajar bagi guru, dosen, siswa maupun mahasiswa.

Materi yang diberikan tim kepada peserta adalah strategi dan teknik benar dalam menulis artikel ilmiah, khususnya yang bertema kepustakawanan dan informasi. Dalam pelaksanaanya, materi diberikan dalam beberapa bagian yaitu; pertama, diberikan bagaimana peserta mengetahui dan memahami pra-penulisan artikel ilmiah, kedua berisi proses dan strategi penulisan artikel ilmiah, dan ketiga peserta pelatihan diberikan tips dan trik bagaimana pengiriman artikel ke jurnal ilmiah.

Gambar 1 Penyampaian Materi oleh Narasumber

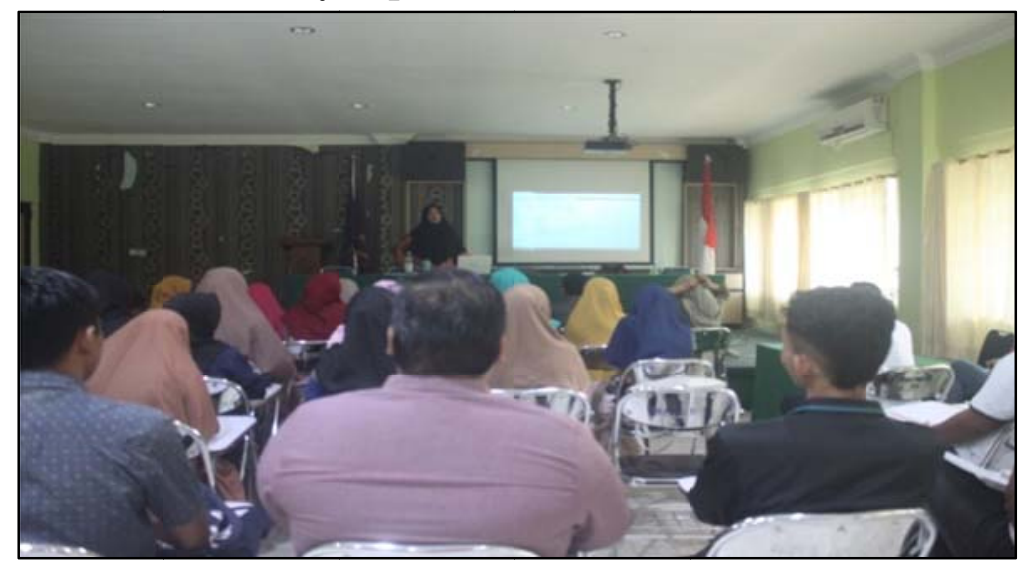


Adapun teknik pelaksanaan kegiatan pelatihan ini dilakukan beberapa tahap. Pertama, dimulai perserta diminta menyiapkan bahan yang akan digunakan dalam gagasan awal artikel. Pada tahap ini dapat dilakukan dengan studi pustaka, diskusi, atau kegiatan penelitian lain yang menunjang persiapan bahan yang akan ditulis.

Tahap kedua, tahap ini merupakan tahap lanjutan dari tahap pertama, yaitu upaya melakukan pengelompokkan informasi berdasarkan keterkaitan dengan topik atau tema artikel yang akan ditulis, serta membuang informasi yang tidak perlu. Tahap ini bertujuan untuk menjaga fokus tulisan, menentukan kerangka tulisan, dan membangun argumentasi.

Tahap ketiga, tahap menulis secara kasar dan terus-menerus. Tahap ini harus dilakukan terus sampai selesai tanpa memperhatikan kesalahan atau koreksi atas konsep, diksi, dan tanda baca tulisan. Kemudian, setelah tulisan selesai, baru dilakukan koreksi. Hal terpenting dalam tahap ini adalah tidak melakukan pengulangan ke awal sebelum tulisan selesai. Artinya, penulis hendaknya tidak membaca tulisannya sebelum tulisan selesai.

Tahap keempat, merupakan tahap mengoreksi dan merevisi tulisan yang telah selesai. Maksudnya, peserta membongkar kembali tulisannya untuk mendapat susunan yang enak dibaca, lebih indah, tertata dan lebih halus serta yang terpenting sesuai dengan sistematika penulisan artikel ilmiah.

Terakhir, yang merupakan proses akhir yang perlu dilakukan ialah melakukan pemeriksaan ulang tulisan dan mengevaluasi. Dalam hal ini, penulis dapat memposisikan diri sebagai pembaca, bukan sebagai penulis. Hal ini untuk mendapatkan informasi ini secara lengkap. Selain itu, untuk menilai secara objektif keindahan tulisan dan kebenaran tata bahasa yang digunakan..

Akibat tanya-jawab antara peserta dengan pemateri sangat antusias, tidak terasa waktu yang disediakan telah selesai. Hal tersebut membuat tim harus tetap memberikan pelayanan dan pendampingan kepada peserta, dengan tujuan agar ilmu yang ditransfer dapat diterima dan dipahami dengan baik oleh peserta sehingga merekan tidak merasa kecewa.

Meskipun dalam pelaksanaan kegiatan pelatihan dapat dikatakan sukses, yang ditndai dengan antusiasme peserta dalam mengikuti pelatihan, dan mengikuti perintah pemateri dengan mengerjakan tugas-tugas yang diberikan, pasti ada sisi kekurangan. Berdasarkan evaluasi oleh tim, ditemukan beberapa hal yang menjadi perbaikan untuk kegiatan yang akan datang. Temuan tersebut antara lain; jumlah peserta yang tidak sesuai target, ada banyak undangan yang tidak menghadiri kegiatan pelatihan, waktu kegiatan yang kurang sesuai dengan rencana. Kegiatan yang sedianya dilaksanakan pada pukul 08.00 WIB, diundur menjadi pukul 09.30 WIB.

Hasil dari kegiatan ini yaitu berupa peningkatan pemahaman dan keterampilan peserta dalam memahami materi yang disampaikan. Peningkatan yang dimaksud yaitu pemahaman dan keterampilan terkait penulisan artikel ilmiah. Dilihat dari hasil evaluasi menggunakan 10 (sepuluh) soal pre-test dan post-test, diperoleh hasil bahwa peserta yang mengikuti pelatihan mengalami peningkatan pemahaman dan keterampilan menulis artikel ilmiah. Hasil tersebut dapat dilihat pada tabel berikut: 
Tabel 1. Hasil Evaluasi Pret-Test dan Post-Test

\begin{tabular}{|c|l|c|c|c|}
\hline No. & \multicolumn{1}{|c|}{ Materi } & Pretest & Post test & Peningkatan \\
\hline 1. & $\begin{array}{l}\text { Pemahaman tentang konsep } \\
\text { artikel ilmiah }\end{array}$ & $57,75 \%$ & $88,50 \%$ & $30,75 \%$ \\
\hline 2. & $\begin{array}{l}\text { Kemampuan strategi dan } \\
\text { teknik menulis artikel ilmiah }\end{array}$ & $61,03 \%$ & $90,67 \%$ & $29,64 \%$ \\
\hline \multicolumn{2}{|l}{ Sumber: data diolah Mei 2019 }
\end{tabular}

Dari data di atas dapat diketahui bahwa seluruh materi yang disampaikan narasumber dapat diterima dan dipahami dengan baik oleh peserta pelatihan. Pada pemahaman tentang konsep artikel ilmiah mengalami peningkatan sebesar 30,75\%, sedangkan pada kemampuan strategi dan teknik menulis artikel ilmiah mengalami peningkatan sebesar 29,64\%. Dari hasil tersebut tim berasumsi bahwa peningkatan pemahaman tersebut dikarenakan antusiasme dan semangat peserta dalam mengikuti kegiatan pelatihan, untuk menambah keterampilan menulis artikel ilmiah tim berharap seluruh peserta mengaplikasikan ilmu yang telah diperoleh dari pelatihan ini.

\section{Refleksi Capaian Program}

Berdasarkan pemaparan hasil kegiatan pelatihan, dapat ditarik kesimpulan bahwa seluruh target yang direncanakan telah tercapai dengan baik dan sesuai. Pelatihan ini mendapat respon positif dari para peserta yang ditandai dengan permintaan pelatihan serupa diwaktu yang akan datang. Selain itu, terjadi peningkatan pemahaman dan keterampilan peserta kegiatan terkait kemampuan menulis artikel. Indikator lain ditunjukkan dengan hasil evaluasi pretest dan post-test mengalami peningkatan yang cukup signifikan. Selain itu, dari hasil kegiatan pelatihan ini menghasilkan luaran berupa artikel ilmiah yang berhasil dikirim ke jurnal Dinamisia.

\section{Penutup}

Beberapa saran yang diberikan tim pelaksana terkait hasil pelatihan ini antara lain sebagai berikut:

1. Dari hasil kegiatan yang telah dilaksanakan sebaiknya menjadi pedoman dan diaplikasikan oleh peserta pelatihan guna memaksimalkan kemampuan individu dan meningkatkan citra baik profesi serta instansi perpustakaan.

2. Melihat kurangnya kegiatan-kegiatan pelatihan bagi pustakawan dan pengembangan pustakawan di Pekanbaru, maka tim pelaksana merasa sangat perlu diadakannya pelatihan-pelatihan yang lain guna memberikan pengetahuan dan keterampilan tambahan dan memaksimalkan potensi pustakawan.

\section{Daftar Pustaka}

Al. Widyamartaya, d. V. (2000). Dasar Dasar Menulis Karya Ilmiah . Jakarta: Grasindo.

Budaya, P. (2012). Jurnal Pustaka Budaya. Retrieved Mei 15, 2019, from www.pustakabudaya.unilak.ac.id: https://journal.unilak.ac.id/index.php/pb 
Dikti. (2011). Materi Pelatihan Penulisan Artikel Ilmiah Nasional. Jakarta: Direktorat Jenderal Pendidikan Tinggi.

Dikti. (2012). Surat edaran penulisan artikel ilmiah No 152/E/T/2012. Jakarta: Direktorat Jenderal Pendidikan Tinggi.

Indonesia, M. R. (2002). Menteri Pendayaan Aparatur Negara dan Reformasi Birokrasi. Retrieved Mei 15, 2019, from www,menpan-rb.go.id: http://pustakawan.perpusnas.go.id/uploads/content/document/attachment/j abatan_fungsional_pustakawan.pdf

Indonesia, P. R. (1999). Badan Pembinaan Hukum Nasional. Retrieved Mei 15, 2019, from www.bphn.go.id

Sudjana, N. (3013). Tuntunan Penyusunan Karya Ilmiah. Bandung: Sinar Baru Algensindo.

Surata, I. W. (2012, Maret 8). Menulis artikel ilmiah. Retrieved 3 10, 2019, from www.google.com/surata-menulis-artikel-7w4567.html/ 